\title{
DEMOGRAPHIC MONITORING AND POPULATION VIABILITY ANALYSIS OF TWO RARE BEARDTONGUES FROM THE UINTA BASIN
}

\author{
Rebecca M. McCaffery1, Rita Reisor ${ }^{2}$, Kathryn Irvine ${ }^{3}$, and Jessi Brunson ${ }^{4}$
}

\begin{abstract}
Energy development, in combination with other environmental stressors, poses a persistent threat to rare species endemic to energy-producing regions of the western United States. Demographic analyses of monitored populations can provide key information on the natural dynamics of threatened plant and animal populations and how these dynamics might be affected by present and future development. In the Uinta Basin in Utah and Colorado, Graham's beardtongue (Penstemon grahamii) and White River beardtongue (Penstemon scariosus var. albifluvis) are 2 rare endemic wildflowers that persist on oil shale habitats that are heavily impacted by current energy exploration and development and are slated for expanded traditional drilling and oil shale development. We described demographic characteristics and population viability for 2 populations of each species that have been monitored since 2004. First, we measured population size, survival rates, transitions between life stages, and recruitment by using individually marked plants at the 4 study areas. We then used matrix population models to determine stochastic population growth rates $(\lambda)$ and the probability that each population would persist 50 years into the future, given current conditions. The 2 P. grahamii study plots had small populations, averaging 70 adult plants, and relatively constant and high survival in both vegetative and flowering plants. The 2 P. scariosus var. albifluvis study plots had populations that averaged 120 adult plants, with high and stable survival in flowering plants and variable survival in vegetative plants. Recruitment of new seedlings into all populations was low and variable, with most recruitment occurring in one or 2 years. Both $P$. grahamii populations had $\lambda$ near 1.0 (stable). One P. scariosus var. albifluvis population appeared to be declining $(\lambda=0.97)$, whereas the other was increasing $(\lambda=1.16)$. Our analyses reveal populations that appear relatively stable, but that are susceptible to declines now and into the future. Increases in environmental variability, deterministic changes in habitat conditions or stressors, or a single catastrophic event could all have immediately deleterious impacts on the long-term growth trajectory of these populations.
\end{abstract}

Resumen.-El desarrollo de la energía, en combinación con otros factores de estrés ambiental, supone una persistente amenaza para las especies raras endémicas en las regiones productoras de energía del oeste de los Estados Unidos. Los análisis demográficos de poblaciones monitoreadas pueden proporcionar información clave sobre la dinámica natural de las poblaciones de animales y plantas amenazadas, y como podrían ser afectados por desarrollos futuros y actuales. En la cuenca del Uinta en Utah y Colorado, la campanilla de Graham (Penstemon grahamii) y la campanilla del Río Blanco (Penstemon scariosus var. albifluvis) son dos flores raras, silvestres y endémicas que subsisten en hábitats que han recibido un fuerte impacto por las actuales exploraciones y desarrollo de energía, y previstos para la perforación tradicional expandida y el desarrollo de la pizarra bituminosa. Describimos las características demográficas y la viabilidad de dos poblaciones de cada especie que fueron monitoreadas desde el 2004. Primero, calculamos el tamaño de la población, las tasas de supervivencia, la transición entre estadios y el reclutamiento utilizando plantas marcadas individualmente en las cuatro áreas de estudio. Luego, modelos poblacionales matriciales para determinar las tasas finitas de crecimiento poblacional $(\lambda)$ y la probabilidad de que cada población persista 50 años en el futuro, dadas las condiciones actuales. Los dos terrenos de estudio de $P$. grahamii tenían pequeñas poblaciones con un promedio de 70 plantas adultas y una supervivencia relativamente constante y alta, tanto en las plantas florales como en las vegetativas. Los dos terrenos de estudio de $P$. scariosus var. albifluvis tenían poblaciones con un promedio de 120 plantas adultas, con supervivencia alta y estable en las plantas florales y supervivencia variable en las plantas vegetativas. El reclutamiento de nuevas plántulas en todas las poblaciones era bajo y variable, con el reclutamiento ocurriendo en uno o dos años. Ambas poblaciones de $P$. grahamii tenían un $\lambda$ cercano a 1.0 (estable). Una población de $P$. scariosus var. albifluvis parecía estar en declive $(\lambda=0.97)$, mientras que la otra iba en aumento $(\lambda=1.16)$. Nuestros análisis revelan poblaciones relativamente estables, pero que son susceptibles a sufrir declives ahora y en el futuro. Aumentos en la variabilidad ambiental, cambios determinantes en las condiciones o factores estresantes del hábitat, o un simple evento catastrófico podrían tener impactos nocivos inmediatos en la trayectoria de crecimiento a largo plazo de estas poblaciones.

Continued energy exploration and development presents a persistent threat to plant and wildlife species endemic to the western United
States. Energy development has impacted both the quantity and the quality of plant and wildlife habitats (e.g., Copeland et al. 2009, Walston

\footnotetext{
${ }^{1}$ University of Montana, Wildlife Biology Program, 32 Campus Dr., Missoula, MT 59812. E-mail: amphibecs@gmail.com

${ }^{2}$ Red Butte Garden and Arboretum, 300 Wakara Way, Salt Lake City, UT 84108.

${ }^{3}$ U.S. Geological Survey, Northern Rocky Mountain Science Center, 2327 University Way, Suite 2, Bozeman, MT 59715.

${ }^{4}$ Bureau of Land Management, Vernal Field Office, 170 South 500 East, Vernal, UT 84078.
} 
et al. 2009, Wilson et al. 2013), and this development can combine with other threats such as ongoing climate change (e.g., Hervieux et al. 2013), disease (e.g., Walker et al. 2007), and encroachment of invasive species (e.g., Bergquist et al. 2007) to further impact sensitive species. Fossil fuels - including oil, natural gas, and coal-continue to be the dominant source of global energy (Chow et al. 2003), making it imperative to understand the natural population dynamics of rare species endemic to energy-producing regions and how these dynamics will be impacted by ongoing energy development.

While some bird and mammal species found in energy-producing regions have been studied in detail (e.g., Doherty et al. 2008, Naugle et al. 2011, Boutin et al. 2012, Hervieux et al. 2013, Wilson et al. 2013), underlying plant communities have received much less attention. In a rare study exploring the impacts of energy development on a big sagebrush (Artemisia tridentata) ecosystem, authors demonstrated both direct impacts of sagebrush habitat loss and indirect effects of sagebrush habitat quality in relation to natural gas development (Walston et al. 2009). This broad-scale analysis may allow resource managers to assess landscapelevel effects of energy development, but it does not address how individual species-especially rare, endemic plants - might be impacted.

Demographic studies provide a means for understanding the natural dynamics of threatened plant populations that inhabit the energy-producing regions of the western United States. Long-term tracking of marked individuals in one or more populations can provide critical information on the vital rates (e.g., survival, transition between life stages, and reproduction) of the population; this information can allow for estimates of population growth rates and probabilities of extinction via matrix population modeling (Caswell 2001, Morris and Doak 2002). In healthy populations, these estimates can provide a baseline for understanding how future threats might impact populations. Demographic models can also help evaluate the impact of various threats to population growth and viability and assess the effectiveness of alternate restoration or management strategies (Morris and Doak 2002, Thomson 2005). Matrix population modeling and population viability modeling are now common tools for examining questions related to plant population conservation, ecology, and management (Menges 2000, Crone et al. 2011).

In this study, we examine the demography and population viability of 2 rare species of beardtongue endemic to oil shale deposits in Utah and Colorado, Graham's penstemon (Penstemon grahamii) and White River penstemon (Penstemon scariosus var. albifluvis). Habitat areas of both species are being increasingly impacted by traditional oil and gas development through road construction, dust production, habitat fragmentation, and possible pollinator disturbance (USFWS 2013). Future planned oil shale development may also further impact both species' habitat (USFWS 2013). The combined factors of climate change (e.g., increasing aridity), invasive weeds, small population size, and grazing pressure have also been identified as potential stressors for these species.

Despite the concern over declines in these 2 species, little is known about their population dynamics and what factors might influence their long-term viability. Previous work on the pollination biology of $P$. scariosus var. albifluvis identified the importance of maintaining a diversity of pollinating bees for the reproductive success of the species (Lewinsohn and Tepedino 2007, Dodge and Yates 2009), as seeds and fruits are best produced when flowers are cross-pollinated. However, very few published studies have examined other elements of the life history and demography of these or other penstemon species (but see Mabry 2011). Understanding basic demographic features of these rare species is critical to determining the dynamics of healthy populations and addressing future effects of energy development or potential restoration efforts.

We estimated survival, reproduction, and population viability by using demographic monitoring data that have been collected on 2 populations of each of these species since 2004. These monitored populations provide robust demographic data sets for examining populationspecific vital rates, population growth rates, and extinction risks. We first summarized population data (i.e., plant abundance) for each population over time, which included determining demographically relevant life stages for analysis. Then, we estimated survival probabilities for each life stage, the probability of transitioning between life stages, and recruitment of new plants to each population over 
time. Finally, we used information on plant abundance and vital rates to estimate population growth rates and risk of extinction over a 50 -year time horizon. We also examined relationships between plant vital rates, growth rates, population sizes, and precipitation to identify possible drivers of local plant population dynamics.

\section{Methods}

\section{Study Species}

Graham's beardtongue (Penstemon grahamii) and White River beardtongue (Penstemon scariosus var. albifluvis) are endemic to the Uinta Basin in northeastern Utah and adjacent western Colorado (Fig. 1). Graham's beardtongue occurs along a horseshoe-shaped band following the Green River shale formation, about $130 \mathrm{~km}$ long and $10 \mathrm{~km}$ wide, extending from the extreme southeastern edge of Duchesne County in Utah to the northwestern edge of Rio Blanco County in Colorado. White River beardtongue's range extends from the vicinity of Willow Creek in Uintah County, Utah, to Raven Ridge west of Rangely in Rio Blanco County, Colorado, although most of the population occurs in the $32 \mathrm{~km}$ between Raven Ridge in Colorado and Evacuation Creek in Utah. It is estimated that there are about $31,700 P$. grahamii individuals and 11,400 P. scariosus var. albifluvis individuals (USFWS 2013). Both species grow on sparsely vegetated calcareous substrates, along with other endemic plant species, and are closely associated with oil shale deposits of the Mahogany ledge within the Green River geologic formation (USFWS 2013). Both Graham's beardtongue and White River beardtongue are herbaceous, long-lived perennial plants that are estimated to live for at least 30 years (USFWS 2012).

We monitored 2 populations of $P$. grahamii, identified as Blue Knoll and Buck Canyon, and 2 populations of $P$. scariosus var. albifluvis, identified as White River and Watson (Fig. 1). These locations were nonrandomly chosen based on early survey reports for populations of both species, and each site has typical soil characteristics and falls within the core range of each species. These populations were chosen because they had a high density of plants, were accessible for monitoring, and were expected to be representative of the species' ranges as they were understood in 2004. These populations are all considered demographically isolated; that is, movement of seeds between populations is considered unlikely.

\section{Field Methods}

At all 4 sites, long-term monitoring transects were established in late April and May 2004. All sites were monitored annually in the spring from 2004 to 2012, except for the Watson site, which was not monitored in 2006 or 2007 due to access restrictions at the site. Therefore, we collected 9 years of data at Blue Knoll, Buck Canyon, and White River, and 7 years of data at Watson. At each site, one or more belt transects were laid out, and every plant within those transects was tagged with a permanent metal tag. The total area surveyed approximated $1000 \mathrm{~m}^{2}$ at each site, though the size, shape, and number of transects differed among sites. Transects were centered on the core plant population at each site (i.e., highest plant density) but did not encompass the entire population at any site. Approximately $90 \%$ of the plants at Blue Knoll, $75 \%$ of the plants at Buck Canyon, $85 \%$ of the plants at White River, and $65 \%$ of the plants at Watson have been monitored with these permanent transects. We generally refer to these monitored transects as "populations" throughout the paper, even though they do not capture the entire population.

For each individually marked plant in each year, we recorded the following data: number of inflorescences, height of the tallest inflorescence, number of flowers and buds per inflorescence, and number of fruits. For P. grahamii, the number of rosettes and total diameter of the rosettes were recorded, and for P. scariosus var. albifluvis, the diameter of the woody base was recorded. Other data that were collected on some years included number of seeds per fruit, presence of herbivory, and general condition of each plant. New plants were marked with permanent metal tags, previously marked plants that were not located were recorded as missing, and previously marked plants that had died or were not seen for 3 consecutive years were recorded as dead.

\section{Summary of Population Data}

For each population of each species, plants were divided into 3 life stage classes: seedlings 


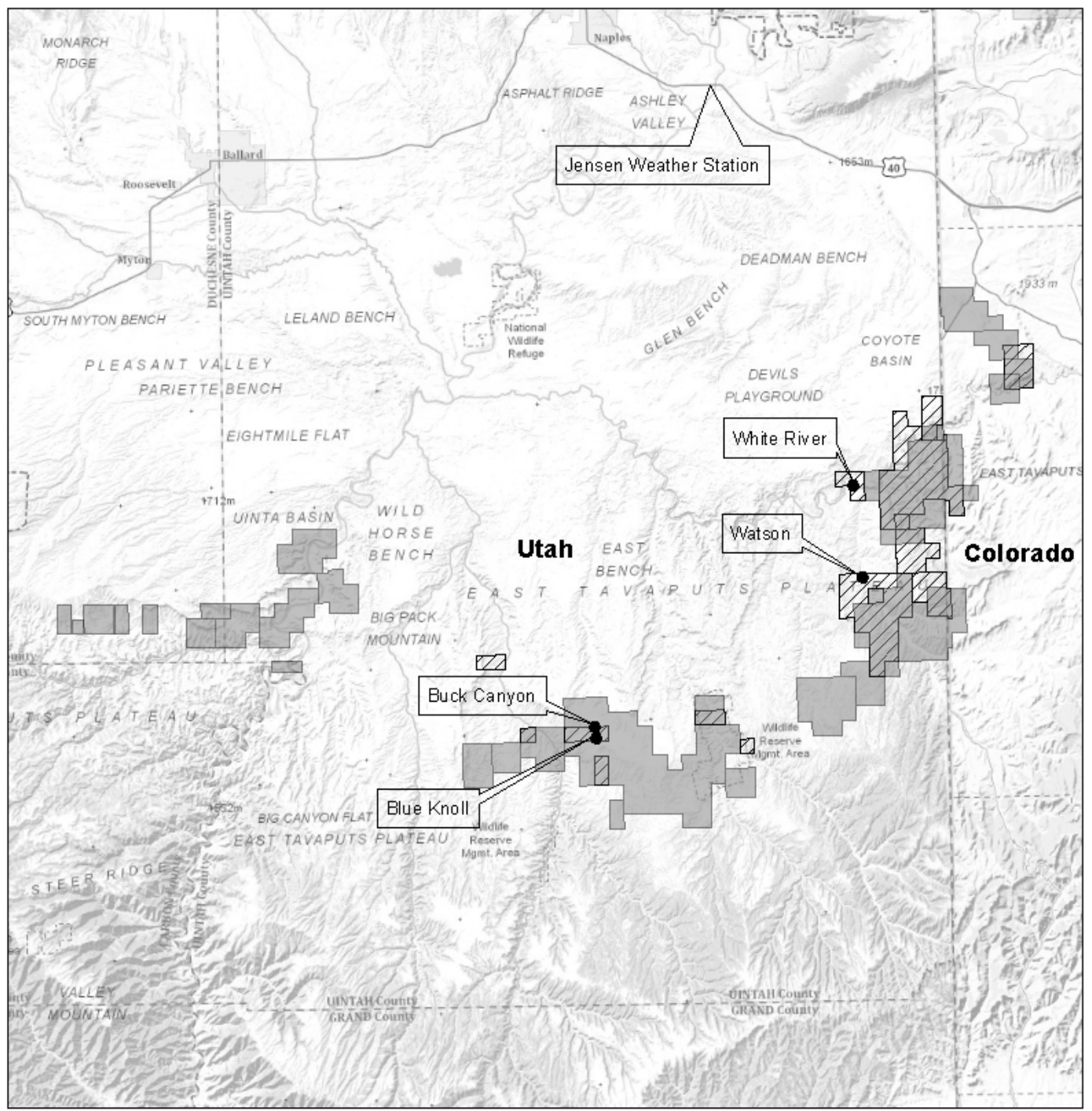

- Monitoring Plot Locations

Graham's Beardtongue Populations

QVIJ White River Beardtongue Populations

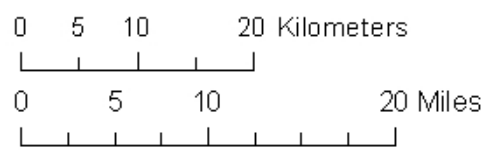

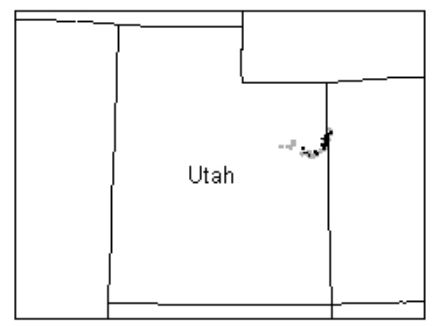

Fig. 1. Map depicting study site locations for Graham's beardtongue (Penstemon grahamii) and White River beardtongue (P. scariosus var. albifluvis) and the ranges of both species.

(S), vegetative adults $(\mathrm{V})$, and flowering adults (F). We did not include other size classes because of the small population sizes. For P. gra- hamii, all new individual plants that were $<3$ $\mathrm{cm}$ in rosette diameter, had a single rosette, and were not flowering were classified as 
seedlings. For P. scariosus var. albifluvis, all new individual plants that were not flowering and had a woody base diameter that was $<3$ $\mathrm{cm}$ were classified as seedlings. A plant could not be a seedling for more than one year. All other plants were classified as either vegetative $(\mathrm{V})$ or flowering $(\mathrm{F})$. Many plants of both species were first detected as either vegetative or flowering, rather than at the seedling stage. In this case, adult plants may have been missed on the transect and tagged in a subsequent year, or difficult-to-detect seedlings were not initially tagged until they had reached the adult vegetative or flowering stage.

There were 2 scenarios where individuals previously seen were not found on a given year: in the first scenario, the tag was located but no plant was seen; in the other, neither the tag nor the plant was located. For the first scenario, tags were left in place to check for potential resprouting or dormancy. After 3 consecutive years of a plant being absent, the tag was removed and the plant recorded as dead. In the second scenario, plants may have been missed by observers due to substrate covering the tags. Some of these individuals were then relocated and observed again on subsequent years. However, especially for $P$. scariosus var. albifluvis, a number of tags went missing and were never seen again. When a tagged plant was not found and not relocated in a subsequent year, it was impossible to determine if it had died, gone dormant, been missed by observers, or moved (e.g., if plant tags had been disturbed by grazers or eroded due to the unstable substrate). Because the total number of individuals monitored at each site was small (generally between 60 and 150 plants per population per year), we chose not to remove any plants from the analysis and to account for the uncertainty in plant status in the estimation of vital rates (see "Survival and Transition Analysis"). For each population, we counted the number of seedlings, vegetative adults, and flowering adults seen each year. This count provided an index of population size for each year that we used as starting population sizes in our matrix models, as well as to estimate trends in abundance over time (see "Viability Analysis").

\section{Survival and Transition Analysis}

For the first part of our analysis, we estimated survival and transition rates for flowering and vegetative stages in all populations. To account for the fact that individual plants sometimes went missing for one or more years and then reappeared, we used multistate mark-recapture models for this analysis. Mark-recapture modeling is a powerful approach for estimating vital rates in populations of animals or plants where individuals are detected imperfectly (Lebreton et al. 1992, White and Burnham 1999). In plant population ecology, markrecapture models have been used infrequently and have largely been developed to measure vital rates surrounding prolonged dormancy in plants (e.g., Shefferson et al. 2001, Kery et al. 2005, Lesica and Crone 2007). The dormancy models tested whether survival differs between observed plants and unobserved (i.e., dormant) plants. However, mark-recapture models can also be used to correct survival estimates for detection probabilities that are $<1$, which is what we do here. In these models, we assume that survival is the same for observed and unobserved transitions. Furthermore, multistate mark-recapture models allow the user to specify a "state," or life stage (e.g., vegetative or flowering), for each sampling occasion (e.g., White et al. 2006). These models, in addition to estimating survival probabilities over time, estimate transition probabilities between states for each time period. For both species, this modeling approach allowed estimation of the probability that a vegetative plant would transition to flowering, and vice versa, between years. Because there were so few seedlings in the data sets for either species, we were not able to model seedling survival rates, or transitions from seedling to vegetative or flowering plants, using mark-recapture models. Therefore, for the survival and transition analysis, we created data files that only tracked the history of individual plants through their adult life stages.

All multistate mark-recapture analyses were conducted in Program MARK (White and Burnham 1999). For each population, we estimated vital rates for a number of different predetermined models to test whether survival probabilities $(S)$, probabilities of detection $(\mathrm{p})$, and transition probabilities $(\psi)$ varied by time $(\mathrm{t})$, life stage $(\mathrm{g})$, or both $\left(\mathrm{t}^{*} \mathrm{~g}\right)$ - e.g., $\mathrm{S}(\mathrm{t} * \mathrm{~g})$. For all populations, we were unable to estimate models where probabilities of detection varied over time. Therefore, the set of models we used had probabilities of detection 
that were either constant or varied simply by life stage. Models were evaluated using Aikaike's information criterion corrected for small sample sizes $\left(\mathrm{AIC}_{c}\right)$; the model with the smallest $\mathrm{AIC}_{c}$ value was considered to have the best fit with the fewest parameters (Burnham and Anderson 2002). When there were multiple models with statistical support (we considered models within $6 \mathrm{AIC}_{c}$ units of the best model), we calculated model-averaged parameter estimates for survival and transition probabilities (Burnham and Anderson 2002).

In addition to the mark-recapture analyses, we made several calculations from the raw data. First, we calculated seedling survival and transition rates by determining the percentage of seedlings counted in one year that survived to the next year, and whether the surviving seedlings transitioned to a vegetative or flowering stage class. Second, we calculated survival and transition estimates for vegetative and flowering plants of each species. As with the seedlings, we calculated survival for each life stage from year $t$ to $t+1$ as

[(\# plants alive in year $t+1)-(\#$ new plants marked in year $t+1)] /$ \# plants alive in year $t$.

For the plants that did survive, we then calculated what percentage of plants transitioned from vegetative to flowering, or from flowering to vegetative, between years $t$ and $t+1$. These calculations provided a comparison to the estimates from the mark-recapture analyses. This type of "naïve" estimation of survival and transition-one that does not adjust for imperfect plant detection-is the type most commonly used in plant population studies (Kaye and Pyke 2003, Ellis et al. 2012).

\section{Reproduction and Recruitment}

For each population, we quantified reproduction as the ratio of new seedlings counted in year $t+1$ to the number of flowering plants counted in year $t$. This commonly used metric for plant reproduction assumes that all new plants come from the previous year's flowering plants, rather than from the seed bank (Ellis et al. 2012). For both species, transitions into and out of the seed bank are not well understood. For P. grahamii, seed density from the seed bank was measured in only 2 years, with different methods used in each year. Furthermore, data on seed germination and seed viability were extremely limited.
Therefore, we were unable to reliably incorporate data from the seed bank into estimates of recruitment. Similarly, we did not have data on the number of seeds produced per fruit over time to include in our estimates of recruitment (data were only collected in 2004 and 2005, and seeds were not found at all sites in those 2 years). In summary, the metric for reproduction that we used provides some useful measure of new plant production per year but is likely to overestimate the rate of seedling production because it does not include the effect of the seed bank (Adams et al. 2005).

The above measure of reproduction only accounted for new seedlings entering the tagged sample, yet many (and in some years, most) individuals were first marked as vegetative or flowering plants. As a result, total recruitment in the plot on each year was often biased low when we only quantified seedling production. Therefore, we also measured recruitment into the vegetative and flowering stage classes for each population in each year, as described in Lesica (1995). For new vegetative plants, recruitment was quantified as the ratio of new vegetative plants in year $t+1$ to the number of flowering plants in year $t$. For new flowering plants, recruitment was quantified as the ratio of new flowering plants in year $t+1$ to the number of flowering plants in year $t$. As with the measure of reproduction above, these ratios assumed that all new plants come from the previous year's flowering plants, rather than from the seed bank. However, this method provided some measure of correction for plants that were not located as seedlings, either because of the difficulty in detecting seedlings or because of the timing of annual surveys.

\section{Viability Analysis}

For the second part of our analysis, we estimated population growth rates and viability for the 4 study sites. To estimate population growth rates and extinction risk, we combined estimates of recruitment, survival, and transition, calculated by methods described above, into a stage-based transition matrix model (Fig. 2). This matrix was based on a life cycle comprising the 3 life stages described above (Fig. 3). For both the matrix and the life cycle, $S$ represented survival rates, $T$ represented transition rates, $\mathrm{F}$ represented seedling recruitment (i.e., ratio of new seedlings to flowering 


Seedlings
TO: Vegetative
Flowering $\left[\begin{array}{cccc}0 & 0 & \mathrm{~F}_{\mathrm{F}} & +0 \\ \mathrm{~S}_{\mathrm{S}} \mathrm{T}_{\mathrm{SV}} & \mathrm{S}_{\mathrm{V}}\left(1-\mathrm{T}_{\mathrm{VF}}\right) & \mathrm{S}_{\mathrm{F}} \mathrm{T}_{\mathrm{FV}} & +\mathrm{R}_{\mathrm{V}} \\ \mathrm{S}_{\mathrm{S}} \mathrm{T}_{\mathrm{SF}} & \mathrm{S}_{\mathrm{V}} \mathrm{T}_{\mathrm{VF}} & \mathrm{S}_{\mathrm{F}}\left(1-\mathrm{T}_{\mathrm{VF}}\right) & +\mathrm{R}_{\mathrm{F}}\end{array}\right]$

Fig. 2. Transition matrix used for both beardtongue species to estimate stochastic population growth rates and extinction probabilities. The capital letters S, T, F, and R refer to survival, transition, fecundity, and recruitment, respectively. The subscript letters S, V, and F refer to the seedling, vegetative adult, and flowering adult life stages, respectively. The values in the "flowering" and "recruitment" columns were added together before any matrix projections were conducted.

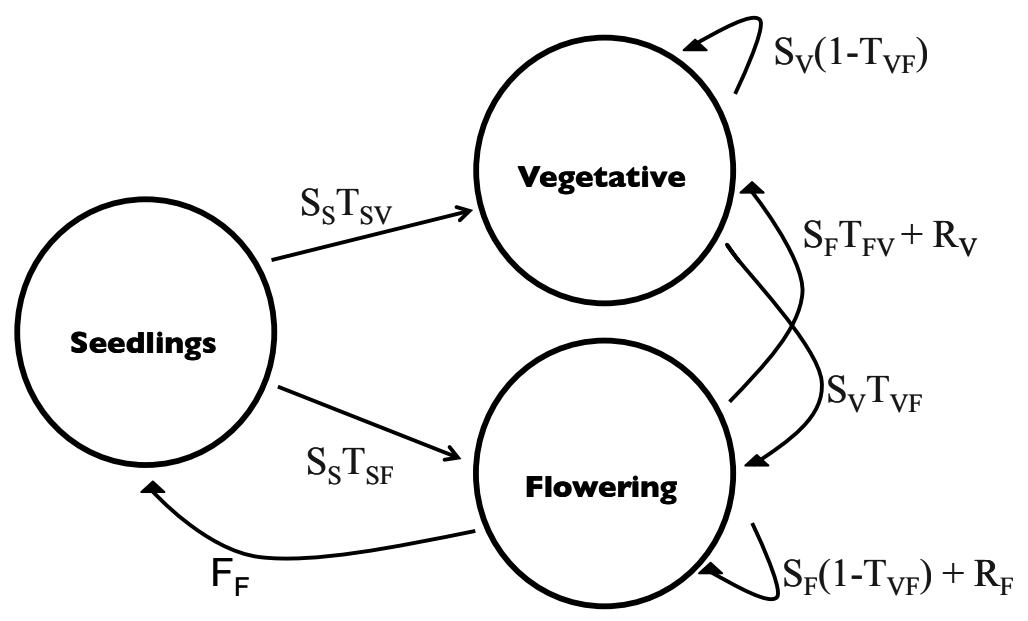

Fig. 3. Penstemon life cycle used to parameterize projection matrix models for both beardtongue species.

plants in the previous year), and $\mathrm{R}$ represented recruitment into the adult life stages. The subscripts $\mathrm{S}, \mathrm{V}$, and $\mathrm{F}$ referred to the 3 life stages: seedling, vegetative adult, and flowering adult. For example, $\mathrm{S}_{\mathrm{V}}$ referred to the survival of vegetative plants, and $\mathrm{T}_{\mathrm{VF}}$ referred to the probability of transitioning from vegetative to flowering between years. The "recruitment" column of the matrix was added to the "flowering" column before any calculations were conducted. We built a separate transition matrix for each population for each year, resulting in 8 transition matrices for each of the 3 populations with continuous data (Blue Knoll, Buck Canyon, and White River): 2004-2005, 20052006, and so on. At the Watson site, no data were collected in 2006 and 2007, so we could only construct 5 transition matrices for this population: 2004-2005, 2008-2009, 2009-2010, 2010-2011, and 2011-2012.
We first estimated the stochastic population growth rate $\left(\lambda_{S}\right)$ for each population by using stochastic computer simulations (Morris and Doak 2002). For this method, we calculated the arithmetic mean of the log ratios of population sizes in adjacent years over many years. Using MATLAB code modified from Morris and Doak (2002), we projected population growth over many successive time intervals, drawing one of the 8 transition matrices ( 5 for the Watson site) at random for each time interval (e.g., Kaye and Pyke 2003). We used these to calculate the number of plants in year $t+1$ (i.e., $\mathrm{N}[t+1])$ from the number of plants in year $t$ (i.e., $\mathrm{N}[t]$ ). We calculated the arithmetic mean and the variance of $\log [\mathrm{N}(t+1) / \mathrm{N}(t)]$ over 50,000 simulated population growth increments to estimate the mean and simulation error of $\lambda_{S}$. Each transition matrix had an equal probability of being drawn on a given 
time interval. In this sense, we assumed that environmental conditions were aperiodic and uncorrelated, and that each matrix represented one demographic manifestation of possible states of the environment.

We then examined population viability over different time horizons by simulating the probability that a given population would go extinct by a specified time in the future. These simulations were based on the 8 transition matrices ( 5 for the Watson site) and the current population size at each site. Again, we used MATLAB code modified from Morris and Doak (2002) for these simulations. For these models, we again used the matrix selection approach described above (e.g., Kaye and Pyke 2003). This process was repeated to look at the projected population size 50 years into the future. We simulated 10,000 different realizations of population growth for each population. We input the initial population sizes for the simulation from the final year of monitoring data (2012), including number of seedlings, vegetative plants, and flowering plants. We set a quasi-extinction threshold of 10 plants; that is, the population was considered extinct if it dropped below 10 individual plants. As with the simulations above, we set the probability of choosing each matrix on a given year as equal. To account for the fact that our study transects did not encompass the whole population at each site, we examined extinction risks for larger starting population sizes that reflected an estimate of the total population size at each study area. We saw no differences in cumulative probabilities of extinction and therefore report the analyses for the monitored study transects.

Finally, we calculated stochastic population growth rates $\left(\lambda_{S}\right)$ and associated confidence intervals for each population by using a time series analysis based on the counts of plants in each year, rather than the underlying vital rates. We used a recently developed method for trend estimation described by Humbert et al. (2009) for these estimates. This approach used state-space models that account for both process noise (i.e., true variation in the data set over time due to environmental variability) and observation error. Ten years of data is typically considered a minimum for analyses of time series of population count data, but these trend estimates provided a useful comparison to the matrix model simulations, especially when determining the best approach for future monitoring of the 2 species. All calculations for this analysis were conducted in $\mathrm{R}(\mathrm{R}$ Core Development Team 2004) using code modified from Humbert et al. (2009).

\section{Relationship to Environmental Variables}

Anecdotal observations have suggested that flowering and recruitment in both beardtongue species may be related to rainfall. To develop this hypothesis and examine these potential relationships, we calculated Pearson's correlations among vital rates, population sizes, and a suite of rainfall metrics for both species. Scatterplots verified that the relationships were linear. Vital rates included survival probabilities, transition probabilities, and asymptotic population growth rates for each matrix. Population sizes included number of seedlings, number of vegetative plants, number of flowering plants, and total number of adult plants (vegetative and flowering). Rainfall metrics included total winter rainfall (October-March), total spring rainfall (AprilMay), total growing season rainfall (FebruaryMay), and total precipitation for the previous year (January-December). Rainfall data were compiled from the Jensen weather station $\left(40.3642^{\circ},-109.345^{\circ}\right.$; $1448 \mathrm{~m}$ elevation), with some precipitation data coming from the Dinosaur Quarry weather station $\left(40.4378^{\circ}\right.$, $-109.304^{\circ}$; $1463 \mathrm{~m}$ elevation) in 2009 when the Jensen station was not working. The Jensen station is located between 46 and 73 $\mathrm{km}$ from the study sites: the White River site is closest at $46 \mathrm{~km}$ and the Blue Knoll site is farthest at $73 \mathrm{~km}$ (Fig. 1). The Dinosaur Quarry station (located about $8 \mathrm{~km}$ north of the Jensen station) is located between 54 and $81 \mathrm{~km}$ from the study sites. Though these regional weather stations might not capture site-specific weather variation, they might capture broad precipitation patterns relevant to the species' reproductive success.

\section{REsults}

\section{Summary of Population Data}

Population size of P. grahamii at Blue Knoll ranged from a low of 52 individuals in 2007 to a high of 114 individuals in 2012 (Fig. 4a). The population largely consisted of adult individuals: seedlings were only counted in 5 of the 9 years, with the largest numbers seen in 


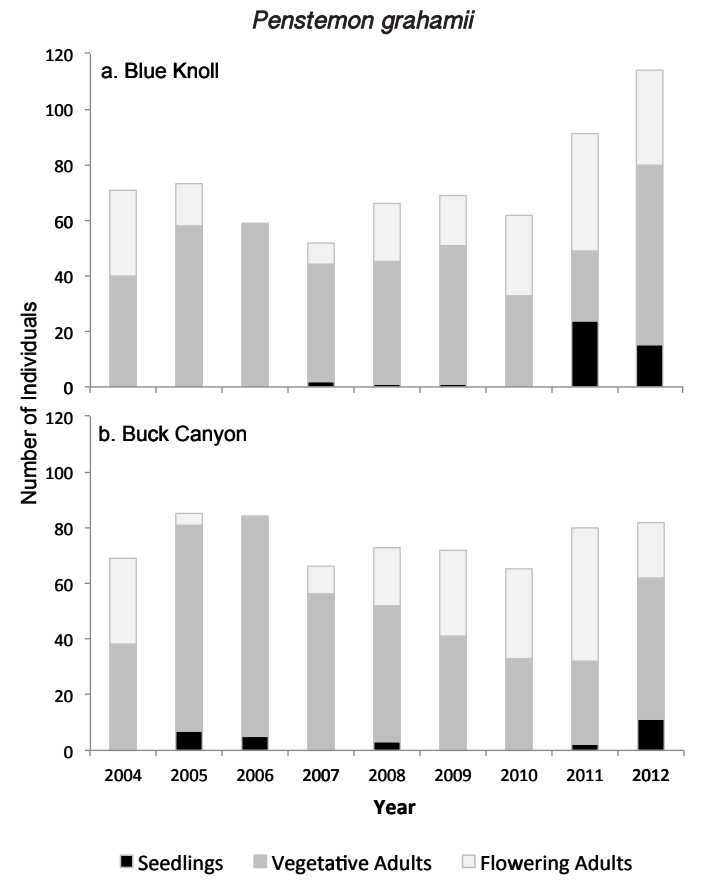

Fig. 4. Population size and life stage distribution over time for Penstemon grahamii at (a) Blue Knoll and (b) Buck Canyon.

2011 and 2012 (24 and 15 seedlings, respectively). The majority of the population consisted of vegetative plants for 7 of the 9 years of the study, with the highest number of flowering plants seen in 2011. The population of $P$. grahamii at Buck Canyon exhibited similar patterns in abundance and distribution, though population numbers were more stable over time at this site (Fig. 4b). Again, seedlings were only counted in 5 of the 9 years, with fewer than 10 seedlings counted in all years but 2012. The majority of plants at this site were also vegetative, except in 2011, when the majority of plants were flowering.

At White River, plant numbers of $P$. scariosus var. albifluvis fluctuated from a low of 87 individuals in 2008 to a high of 230 individuals in 2009 (Fig. 5a). The high population size in 2009 was driven by a large pulse of seedling recruitment; little to no recruitment was observed in the remaining years. Whereas the early years were dominated by flowering plants, proportions of flowering and vegetative plants were more similar in

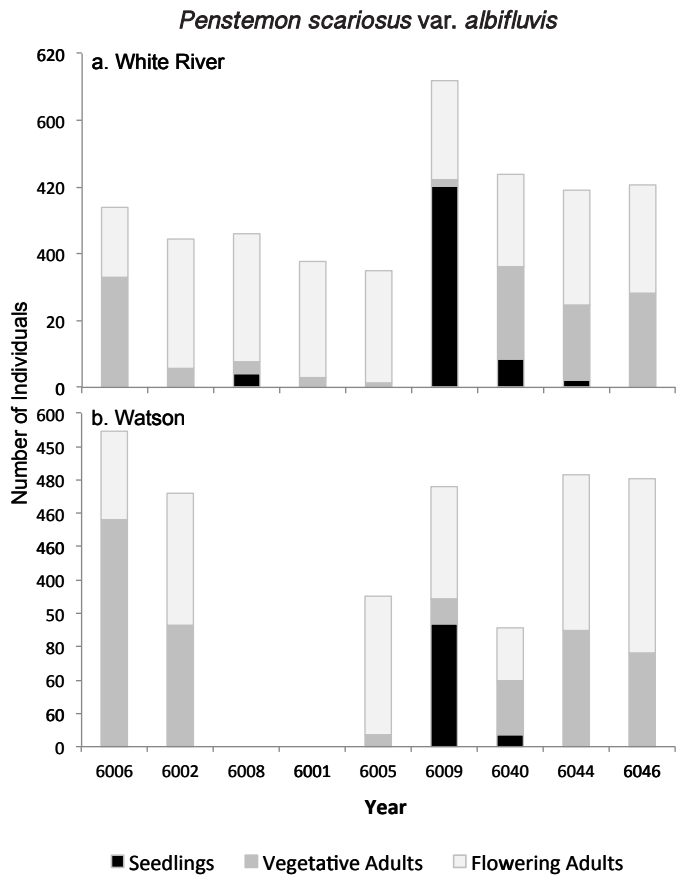

Fig. 5. Population size and life stage distribution over time for Penstemon scariosus var. albifluvis at (a) White River and (b) Watson. Data were not collected at the Watson site in 2006-2007 due restrictions on site access.

the last 3 years of the study. At the Watson site, $P$. scariosus var. albifluvis plant numbers varied considerably as well, from 189 in 2004 to only 71 plants in 2010 (Fig. 5b). As with White River, a large pulse of seedling recruitment was observed in 2009; the only other year with seedlings observed was 2010. The majority of adult plants flowered in most years, showing general patterns similar to those at the White River site.

\section{Survival and Transition Analysis}

At both long-term $P$. grahamii sites, the top models for survival and transition probabilities had survival that varied over time but not by life stage (i.e., survival of flowering plants was the same as for vegetative plants), probabilities of detection that either varied by life stage or were constant, and transition probabilities that varied by both time and life stage (Table 1). The top 2 models at each site had considerable statistical support; therefore, we calculated model-averaged parameter values for survival and transition probabilities using these 2 models. 
TABLE 1. Model selection results for survival and transition analyses at the Blue Knoll, Buck Canyon, White River, and Watson sites. Models depicted were the top models in each analysis, and were used to calculate model-averaged estimates of survival and transition probabilities for each population. Other models (not shown) were $>6$ AIC units from the top model. S, p, and $\psi$ refer to survival, detection, and transition probabilities, respectively. These parameters were held constant (.), or allowed to vary by time $(\mathrm{t})$, life stage $(\mathrm{g})$, or both $\left(\mathrm{t}^{*} \mathrm{~g}\right)$.

\begin{tabular}{|c|c|c|c|c|c|c|}
\hline Model & $\mathrm{AIC}_{c}$ & $\Delta \mathrm{AIC}_{c}$ & $\begin{array}{c}\mathrm{AIC}_{c} \\
\text { weights }\end{array}$ & $\begin{array}{c}\text { Model } \\
\text { likelihood }\end{array}$ & $\begin{array}{l}\text { Number of } \\
\text { Parameters }\end{array}$ & Deviance \\
\hline \multicolumn{7}{|l|}{ Blue Knoll } \\
\hline$\left\{\mathrm{S}(\mathrm{t}) \mathrm{p}(\mathrm{g}) \psi\left(\mathrm{t}^{*} \mathrm{~g}\right)\right\}$ & 1036.08 & 0.00 & 0.60 & 1.00 & 25 & 360.27 \\
\hline$\{\mathrm{S}(\mathrm{t}) \mathrm{p}(.) \psi(\mathrm{t} * \mathrm{~g})\}$ & 1036.90 & 0.83 & 0.40 & 0.66 & 24 & 363.30 \\
\hline \multicolumn{7}{|l|}{ Buck Canyon } \\
\hline$\left\{\mathrm{S}(\mathrm{t}) \mathrm{p}(.) \psi\left(\mathrm{t}^{*} \mathrm{~g}\right)\right\}$ & 1068.69 & 0.00 & 0.54 & 1.00 & 24 & 421.44 \\
\hline$\left\{\mathrm{S}(\mathrm{t}) \mathrm{p}(\mathrm{g}) \psi\left(\mathrm{t}^{*} \mathrm{~g}\right)\right\}$ & 1069.05 & 0.35 & 0.45 & 0.84 & 25 & 419.61 \\
\hline \multicolumn{7}{|l|}{ White River } \\
\hline$\{\mathrm{S}(\mathrm{g}) \mathrm{p}(.) \psi(\mathrm{t} * \mathrm{~g})\}$ & 1600.28 & 0.00 & 0.39 & 1.00 & 19 & 340.77 \\
\hline$\left\{\mathrm{S}\left(\mathrm{t}^{*} \mathrm{~g}\right) \mathrm{p}(.) \psi\left(\mathrm{t}^{*} \mathrm{~g}\right)\right\}$ & 1600.83 & 0.55 & 0.30 & 0.76 & 33 & 311.57 \\
\hline$\left\{\mathrm{S}\left(\mathrm{t}^{*} \mathrm{~g}\right) \mathrm{p}(\mathrm{g}) \psi\left(\mathrm{t}^{*} \mathrm{~g}\right)\right\}$ & 1602.14 & 1.86 & 0.15 & 0.40 & 34 & 310.72 \\
\hline$\left\{\mathrm{S}(\mathrm{g}) \mathrm{p}(\mathrm{g}) \psi\left(\mathrm{t}^{*} \mathrm{~g}\right)\right\}$ & 1602.37 & 2.09 & 0.14 & 0.35 & 20 & 340.76 \\
\hline \multicolumn{7}{|l|}{ Watson } \\
\hline$\left\{\mathrm{S}\left(\mathrm{t}^{*} \mathrm{~g}\right) \mathrm{p}(\mathrm{g}) \psi\left(\mathrm{t}^{*} \mathrm{~g}\right)\right\}$ & 1746.90 & 0.00 & 1.00 & 1.00 & 26 & 458.30 \\
\hline
\end{tabular}

Survival varied over time for both $P$. grahamii populations, but the difference was larger at the Blue Knoll population, where survival was low in the early years and increased in the later years of the study (Table 2). By contrast, survival at Buck Canyon was high and relatively stable throughout the study period. For both populations, transition probabilities from vegetative to flowering were very low in the early years of the study and increased in later years. The reverse is seen in the transition from flowering to vegetative plants over time. The survival estimates from program MARK tracked the estimates we calculated from the raw data but were consistently higher, reflecting corrected estimates for imperfect detection of plants.

Seedling survival varied considerably among years for both the Blue Knoll and Buck Canyon sites (Table 3), and these rates were based on very few seedlings in most years. At both sites, nearly all surviving seedlings transitioned to vegetative plants in the following year rather than to flowering.

In contrast to $P$. grahamii, top models for both populations of $P$. scariosus var. albifluvis indicated that survival and transition probabilities varied by both time and life stage. At the White River site, the best models for survival and transition probabilities had survival varying by life stage only, or by life stage and time (Table 1). Transition probabilities varied by both life stage and time, and there was support for models where detection probability was constant or varied by life stage. There was statistical support for the top 4 models, so we calculated model-averaged parameter estimates using these 4 models. At the Watson site, the best model had survival and transition probabilities that varied by time and with life stage, and capture probabilities that varied by life stage (Table 1). No other models had statistical support, so we used parameter estimates from this model for subsequent analyses.

At the White River site, survival of vegetative plants varied considerably over time, whereas survival of flowering plants was more consistent and higher (Table 2). Similarly, at the Watson site, survival of flowering plants tended to be higher than survival of vegetative plants. Most plants in the White River and Watson populations were flowering on most years, and this is reflected in the transition probabilities: transitions from vegetative to flowering were much higher than transitions from flowering to vegetative, except in the final year of the study at White River (Table 2). As with P. grahamii, the estimates from the mark-recapture analyses were consistent with calculations of survival and transition rates from the raw data but tended to be higher as the estimates were corrected for imperfect plant detection.

As with $P$. grahamii, seedling survival of P. scariosus var. albifluvis varied substantially among years, especially at the White River 
TABLE 2. Parameter estimates for adult survival and transition probabilities. Values are model-averaged estimates from program MARK (with the standard error of the estimate in parentheses). At the Watson site, time intervals with "ND" are years with no data. $\mathrm{V}=$ vegetative, $\mathrm{F}=$ flowering.

\begin{tabular}{|c|c|c|c|c|}
\hline \multirow[b]{2}{*}{ Site and year } & \multicolumn{4}{|c|}{ Vital rate } \\
\hline & V Survival & F Survival & Transition V-F & Transition F-V \\
\hline \multicolumn{5}{|l|}{ Blue Knoll } \\
\hline 2004-2005 & $0.601(0.059)$ & $0.601(0.059)$ & $0.089(0.060)$ & $0.761(0.102)$ \\
\hline $2005-2006$ & $0.655(0.057)$ & $0.655(0.057)$ & $0(0)$ & $1(0)$ \\
\hline $2006-2007$ & $0.496(0.065)$ & $0.496(0.065)$ & $0.268(0.085)$ & $0(0)$ \\
\hline $2007-2008$ & $0.844(0.051)$ & $0.844(0.051)$ & $0.365(0.082)$ & $0.433(0.182)$ \\
\hline $2008-2009$ & $0.971(0.022)$ & $0.971(0.022)$ & $0.156(0.058)$ & $0.422(0.108)$ \\
\hline $2009-2010$ & $0.957(0.025)$ & $0.957(0.025)$ & $0.427(0.073)$ & $0.343(0.117)$ \\
\hline $2010-2011$ & $0.988(0.016)$ & $0.988(0.016)$ & $0.592(0.087)$ & $0.331(0.084)$ \\
\hline 2011-2012 & $1(0)$ & $1(0)$ & $0.480(0.099)$ & $0.496(0.077)$ \\
\hline \multicolumn{5}{|l|}{ Buck Canyon } \\
\hline 2004-2005 & $0.846(0.044)$ & $0.846(0.044)$ & $0.093(0.051)$ & $1(0)$ \\
\hline $2005-2006$ & $0.910(0.035)$ & $0.910(0.035)$ & $0(0)$ & $1(0)$ \\
\hline $2006-2007$ & $0.786(0.047)$ & $0.786(0.047)$ & $0.161(0.047)$ & $0(0)$ \\
\hline $2007-2008$ & $0.926(0.032)$ & $0.926(0.032)$ & $0.199(0.055)$ & $0.539(0.165)$ \\
\hline 2008-2009 & $0.973(0.020)$ & $0.973(0.020)$ & $0.335(0.067)$ & $0.334(0.103)$ \\
\hline $2009-2010$ & $0.972(0.020)$ & $0.972(0.020)$ & $0.372(0.079)$ & $0.435(0.093)$ \\
\hline $2010-2011$ & $0.992(0.014)$ & $0.992(0.014)$ & $0.651(0.078)$ & $0.426(0.086)$ \\
\hline $2011-2012$ & $0.905(0.044)$ & $0.905(0.044)$ & $0.159(0.073)$ & $0.634(0.073)$ \\
\hline \multicolumn{5}{|l|}{ White River } \\
\hline $2004-2005$ & $0.822(0.033)$ & $0.900(0.026)$ & $0.849(0.044)$ & $0.089(0.043)$ \\
\hline $2005-2006$ & $0.835(0.061)$ & $0.922(0.019)$ & $0.672(0.135)$ & $0.045(0.022)$ \\
\hline $2006-2007$ & $0.631(0.091)$ & $0.873(0.024)$ & $1(0)$ & $0.025(0.017)$ \\
\hline $2007-2008$ & $0.892(0.015)$ & $0.902(0.022)$ & $0.858(0.132)$ & $0.026(0.018)$ \\
\hline 2008-2009 & $0.581(0.138)$ & $0.923(0.019)$ & $1(0)$ & $0.065(0.028)$ \\
\hline $2009-2010$ & $0.801(0.101)$ & $0.923(0.020)$ & $1(0)$ & $0.056(0.030)$ \\
\hline $2010-2011$ & $0.780(0.039)$ & $0.877(0.026)$ & $0.450(0.074)$ & $0.024(0.022)$ \\
\hline 2011-2012 & $0.822(0.045)$ & $0.947(0.017)$ & $0.230(0.063)$ & $0.299(0.048)$ \\
\hline \multicolumn{5}{|l|}{ Watson } \\
\hline 2004-2005 & $0.702(0.043)$ & $1(0)$ & $0.445(0.053)$ & $0.172(0.052)$ \\
\hline $2005-2006$ & ND & ND & ND & ND \\
\hline $2006-2007$ & ND & ND & ND & ND \\
\hline $2007-2008$ & ND & ND & ND & ND \\
\hline 2008-2009 & $1(0)$ & $0.957(0.033)$ & $0.432(0.187)$ & $0.139(0.038)$ \\
\hline 2009-2010 & $0.946(0.062)$ & $0.861(0.045)$ & $0.865(0.089)$ & $0(0)$ \\
\hline $2010-2011$ & $0.870(0.064)$ & $1(0)$ & $0.436(0.104)$ & $0.033(0.019)$ \\
\hline $2011-2012$ & $0.915(0.059)$ & $1(0)$ & $0.444(0.069)$ & $0.176(0.037)$ \\
\hline
\end{tabular}

site (Table 3). However, in contrast to P. grahamii, up to a third of surviving $P$. scariosus var. albifluvis seedlings transitioned to flowering plants in the subsequent year rather than transitioning to vegetative plants.

\section{Reproduction and Recruitment}

Recruitment of new seedlings into the 2 P. grahamii populations was low and variable (Table 4): rarely was more than one seedling produced per flowering plant the previous year. Furthermore, the small amount of seedling recruitment that did occur at these sites often occurred on different years between the 2 sites. Notably, recruitment of new vegetative plants occurred in 6 of the 8 time intervals at Blue Knoll, and 5 of the 8 time intervals at
Buck Canyon. Recruitment of new flowering plants was more rare.

As with $P$. grahamii, recruitment of new seedlings into the P. scariosus var. albifluvis populations was also low and variable (Table 4). Although P. scariosus var. albifluvis had one year of high recruitment at both longterm sites, the high proportion of flowering plants in the population still resulted in a low recruitment ratio. Also, P. scariosus var. albifluvis had much less recruitment into the vegetative and flowering life stages compared to $P$. grahamii.

\section{Viability Analysis}

For $P$. grahamii, results of the stage-based matrix population viability analysis indicated 
TABle 3. Parameter estimates for seedling survival and transition probabilities. Values were calculated from the raw data for all sites. Dashes represent years with no reproduction. At the Watson site, time intervals with "ND" are years with no data. $\mathrm{S}=$ seedling, $\mathrm{V}=$ vegetative, $\mathrm{F}=$ flowering.

\begin{tabular}{|c|c|c|c|}
\hline \multirow[b]{2}{*}{ Site and year } & \multicolumn{3}{|c|}{ Vital rate } \\
\hline & $\begin{array}{c}\mathrm{S} \\
\text { survival }\end{array}$ & $\begin{array}{c}\text { Transition } \\
\text { S-V }\end{array}$ & $\begin{array}{c}\text { Transition } \\
\text { S-F }\end{array}$ \\
\hline \multicolumn{4}{|l|}{ Blue Knoll } \\
\hline 2004-2005 & - & - & - \\
\hline 2005-2006 & - & - & - \\
\hline $2006-2007$ & - & - & - \\
\hline 2007-2008 & 0.5 & 1 & 0 \\
\hline 2008-2009 & 1 & 1 & 0 \\
\hline 2009-2010 & 0 & 0 & 0 \\
\hline 2010-2011 & - & - & - \\
\hline 2011-2012 & 0.92 & 0.96 & 0.04 \\
\hline \multicolumn{4}{|l|}{ Buck Canyon } \\
\hline 2004-2005 & - & - & - \\
\hline 2005-2006 & 0.86 & 1 & 0 \\
\hline 2006-2007 & 0.8 & 1 & 0 \\
\hline 2007-2008 & - & - & - \\
\hline 2008-2009 & 0.33 & 1 & 0 \\
\hline 2009-2010 & - & - & - \\
\hline 2010-2011 & - & - & - \\
\hline 2011-2012 & 1 & 1 & 0 \\
\hline \multicolumn{4}{|l|}{ White River } \\
\hline 2004-2005 & - & - & - \\
\hline 2005-2006 & - & - & - \\
\hline 2006-2007 & 0.80 & 0.63 & 0.38 \\
\hline 2007-2008 & - & - & - \\
\hline 2008-2009 & - & - & - \\
\hline 2009-2010 & 0.52 & 0.85 & 0.15 \\
\hline 2010-2011 & 0.81 & 0.77 & 0.24 \\
\hline 2011-2012 & 0.60 & 1 & 0 \\
\hline \multicolumn{4}{|l|}{ Watson } \\
\hline 2004-2005 & - & - & - \\
\hline 2005-2006 & ND & ND & ND \\
\hline $2006-2007$ & ND & ND & ND \\
\hline 2007-2008 & ND & ND & ND \\
\hline 2008-2009 & - & - & - \\
\hline 2009-2010 & 0.58 & 0.72 & 0.28 \\
\hline 2010-2011 & 0.57 & 0.75 & 0.25 \\
\hline 2011-2012 & - & - & - \\
\hline
\end{tabular}

that both populations have growth rates near 1.0 (stable). At Blue Knoll, the stochastic population growth rate was 1.026 (1.0231.028 simulation error), indicating a stable population. Similarly, the Buck Canyon population had a stochastic population growth rate of 1.025 (1.023-1.027 simulation error). Given the current data on the population, the Blue Knoll population has an $8 \%$ chance of declining to 10 or fewer individuals in the next 50 years, and the Buck Canyon population has a $<1 \%$ chance of declining to 10 or fewer individuals in the next 50 years.
TABLE 4. Recruitment values calculated for the 4 beardtongue populations. Recruitment to each life stage is calculated as the ratio of new individuals in year $t+1$ to the number of flowering plants in year $t$. Dashes represent years with no new individuals added. At the Watson site, time intervals with "ND" are years with no data.

\begin{tabular}{|c|c|c|c|}
\hline \multirow[b]{2}{*}{ Site and year } & \multicolumn{3}{|c|}{ Vital rate } \\
\hline & $\underset{\text { recruitment }}{S}$ & $\frac{\mathrm{V}}{\text { recruitment }}$ & $\underset{\text { recruitment }}{\mathrm{F}}$ \\
\hline \multicolumn{4}{|l|}{ Blue Knoll } \\
\hline 2004-2005 & - & 0.74 & 0.29 \\
\hline 2005-2006 & - & 0.80 & - \\
\hline 2006-2007 & 2.00 & - & 1.00 \\
\hline 2007-2008 & 0.13 & 2.63 & 0.13 \\
\hline 2008-2009 & 0.05 & 0.24 & - \\
\hline 2009-2010 & - & - & - \\
\hline 2010-2011 & 0.83 & 0.03 & 0.10 \\
\hline 2011-2012 & 0.36 & 0.07 & - \\
\hline \multicolumn{4}{|l|}{ Buck Canyon } \\
\hline 2004-2005 & 0.23 & 0.74 & - \\
\hline 2005-2006 & 1.25 & 0.75 & - \\
\hline 2006-2007 & - & - & - \\
\hline 2007-2008 & 0.30 & 0.30 & 0.50 \\
\hline 2008-2009 & - & - & - \\
\hline 2009-2010 & - & - & - \\
\hline 2010-2011 & 0.06 & 0.06 & 0.09 \\
\hline 2011-2012 & 0.23 & 0.04 & - \\
\hline \multicolumn{4}{|l|}{ White River } \\
\hline 2004-2005 & - & - & - \\
\hline 2005-2006 & 0.10 & 0.01 & 0.01 \\
\hline $2006-2007$ & - & - & - \\
\hline $2007-2008$ & - & - & 0.02 \\
\hline 2008-2009 & 1.80 & - & - \\
\hline 2009-2010 & 0.28 & - & - \\
\hline 2010-2011 & 0.07 & 0.19 & - \\
\hline 2011-2012 & - & - & - \\
\hline \multicolumn{4}{|l|}{ Watson } \\
\hline 2004-2005 & - & 0.23 & 0.04 \\
\hline 2005-2006 & ND & ND & ND \\
\hline 2006-2007 & ND & ND & ND \\
\hline 2007-2008 & ND & ND & ND \\
\hline 2008-2009 & 0.89 & - & - \\
\hline 2009-2010 & 0.09 & - & 0.01 \\
\hline 2010-2011 & - & 1.52 & 0.10 \\
\hline 2011-2012 & - & - & - \\
\hline
\end{tabular}

For P. scariosus var. albifluvis, results of stage-based matrix population viability analysis indicated that the White River population was declining while the Watson population was growing. The stochastic population growth rate was 0.969 (0.966-0.972 simulation error) for White River and 1.156 (1.1531.160 simulation error) at the Watson site. Given current conditions, the White River site has a $23 \%$ chance of declining to fewer than 10 individuals in the next 50 years. The Watson population is not expected to decline to 10 or fewer individuals over the next 50 years. 
Results of the time series analyses yielded slightly different mean values for population growth rates, though confidence intervals generally overlapped results from the matrix analyses. At Blue Knoll, the estimated growth rate was 1.042 (CI 0.904-1.203), whereas at Buck Canyon, it was 0.997 (CI 0.978-1.016). At White River, the analysis yielded a population growth rate of 1.015 (CI 0.863-1.194). Finally, at Watson, the population growth rate was 0.974 (CI $0.651-1.455$ ). These population growth rates reflect that all populations but Watson were stable or showed an increase in the number of individuals counted over the monitoring period.

\section{Relationship to Environmental Variables}

We found no major patterns between rainfall and either plant numbers or vital rate estimates for either species. The only statistically significant correlation we detected was between spring precipitation and the transition from vegetative to flowering at the Buck Canyon population $\left(r^{2}=0.817, P=0.013\right)$.

As with $P$. grahamii, we did not detect any patterns between rainfall and plant numbers or vital rates for $P$. scariosus var. albifluvis at the White River or Watson sites. The only significant correlation was between winter precipitation and the number of vegetative plants seen the following spring $\left(r^{2}=-0.699\right.$, $P=0.036)$. Despite this relatively strong negative correlation, there was no significant correlation between winter precipitation and the number of flowering plants the following spring $\left(r^{2}=0.555, P=0.121\right)$, suggesting that this correlation is spurious.

\section{Discussion}

Populations of both $P$. grahamii and $P$. scariosus var. albifluvis appear to have high adult survival and population growth rates near 1.0. These features suggest that in their current environment and while they were monitored, these populations have been stable. Should similar conditions persist in the future and habitat conditions remain unchanged, these populations have a low or no probability of going extinct. However, monitored populations were small $(<150$ individuals) and isolated, and had low and variable recruitment. These features make them particularly susceptible to stochastic environmental conditions or deterministic changes in habitat quality or quantity due to proposed energy exploration or other factors (Mace and Kershaw 1997, Purvis et al. 2000). However, each species has some unique demographic characteristics, which may ultimately influence its resilience to environmental and landscape change in the future. Monitoring of our established plots is continuing; new demographic plots have been added in the past 3 years to better represent the species range; and new studies of the seed bank and recruitment dynamics are underway. Continued research will allow us to refine our understanding of the population dynamics of these 2 species across their ranges.

\section{Survival and Transition Analysis}

The analysis of plant life stage composition and adult vital rates (survival and transition rates) at the 4 populations revealed some notable differences among both species and sites. For P. grahamii, survival of flowering plants and vegetative plants was similar within each year, whereas for $P$. scariosus var. albifluvis, survival in flowering plants was high and stable, and variable in vegetative plants. Across all years and sites, P. scariosus var. albifluvis had a higher probability of transitioning from vegetative to flowering than $P$. grahamii. Furthermore, $P$. grahamii had a much lower proportion of flowering plants in most years than $P$. scariosus var. albifluvis, for which the majority of plants flowered on most years whether or not successful recruitment occurred. This suggests that for $P$. grahamii, plants may not flower except when conditions are perceived as good (years with flowers often coincided with or were followed by years with seedling recruitment). In contrast, for P. scariosus var. albifluvis, flowering may be the default strategy in a given year and not associated with seedling recruitment. These life history differences could be useful to monitor across a broader landscape of populations in order to understand the drivers and consequences of variability of flowering in the 2 species.

Our survival estimates for these 2 species generally seem to be quite high, which we would expect from a long-lived species. We only found one other study that estimated survival in a penstemon species (Mabry 2011), 
and mark-recapture models were not used. In that study, survival was monitored in 2 small cohorts of a natural P. tubiflorus population. Percent survival in the first year of this study was high: $91 \%$ and $78 \%$ for the 2 cohorts. Over the 5 years of the study, more individuals died, resulting in $46 \%$ and $50 \%$ survival within the cohort at the end of the study. While these survival percentages are difficult to compare directly to our study, they are similar to the range of survival probabilities we estimated for $P$. grahamii and $P$. scariosus var. albifluvis (Table 2). In contrast, researchers using known-fate models to analyze survival in 29 perennial grassland forbs in Kansas found that first-year survival ranged from 0.106 (Solidago rigida, with a maximum estimated lifespan of 3 years) to 0.487 (Scutellaria resinosa, with a maximum estimated lifespan of 13 years) for these shorter-lived species (Lauenroth and Adler 2008). No Plantaginaceae species were included in this latter analysis.

\section{Reproduction and Recruitment}

One remaining area of high uncertainty is how, why, and when the 2 species reproduce. As we described in the methods, the current analyses use a simple ratio of flowering plants to new seedlings to quantify reproduction, which is an approach commonly used in plant matrix models (Menges 2000). This approach ignores potentially crucial contributions of the seed bank to reproduction (Menges 2000, Adams et al. 2005). For both species, the number of flowering plants in a given year was highly correlated to both the total number of flowers produced that year and the total number of fruits observed. However, due to extremely limited data on seeds, it is unclear how these potential metrics of reproduction relate to the actual number of seeds produced in a given year. Understanding how many seeds are produced by the flowering plants each year, and comparing that to the density and viability of seeds found in the seed bank over time, would help disentangle the relative contribution of the seed bank and flowering plants to annual recruitment. Because recruitment appears to be low and sporadic for both species, we are currently undertaking smallscale studies to better understand the seed banks for these species.
The factors driving frequency of recruitment are also uncertain. A single seedling recruitment pulse in 2009 was observed for the 2 P. scariosus var. albifluvis populations. This pulse drove the higher population sizes seen toward the end of the study. For P. grahamii, seedling recruitment was low, with the highest recruitment occurring toward the end of the study as well. This again resulted in slightly higher population sizes at the end of the study than at the beginning. It is unknown whether this type of sporadic recruitment is typical of these 2 species and whether seedling recruitment may increase or decrease in number and frequency into the future. Similarly variable recruitment was observed for P. tubiflorus (Mabry 2011). Understanding the causes and consequences of sporadic recruitment will be important to ascertaining extinction risk in these 2 species (Higgins et al. 2000) and could aid in conservation or restoration efforts (Humphrey and Schupp 1999). Continued monitoring of these and other populations will be necessary to increase understanding of both the frequency and the drivers of seedling recruitment. We have recently established plots to monitor seedling recruitment in more detail, and we will continue to study germination and recruitment in both species in conjunction with demographic monitoring of adult plants.

All work on the pollination biology of $P$. scariosus var. albifluvis (Lewinsohn and Tepedino 2007, Dodge and Yates 2009), P. tubiflorus (Mabry 2011), and P. haydenii (Tepedino et al. 2007) indicates that self-pollination is limited for these rare western species. Therefore, maintaining a suite of native pollinators may be important to recruitment in these species. It is unknown how energy development and other threats might impact pollinator diversity at this site, or to what extent currently observed recruitment rates might be influenced by pollinators.

\section{Viability Analysis}

The examination of plant abundances over time, stage-based matrix population viability analyses, and time series analyses all reveal populations that are relatively stable but susceptible to declines now and into the future. Because there was some variation between the 2 methods for assessing population 
growth rates, and because these rates were close to 1 , no population could definitively be identified as increasing or decreasing. Though mean values for population growth rates sometimes differed between the 2 analysis methods, confidence intervals from the time series analyses generally contained the stochastic population growth estimates from the matrix analysis, suggesting no dramatic differences between the 2 methods. Because estimated population growth rates and associated confidence intervals were close to 1 , increases in environmental variability, deterministic changes in habitat conditions or stressors, or a single catastrophic event could all have immediate deleterious impacts on the long-term growth trajectory of any of these populations.

The population viability analyses also revealed some site differences. For $P$. grahamii, at Blue Knoll, survival was much lower and more variable in the early years than at Buck Canyon. This pattern in survival likely contributed to the lower population viability seen from the matrix model analysis at Blue Knoll compared to Buck Canyon, even though the population grew more and abundances were generally higher at Blue Knoll. Increased interannual variability in vital rates tends to decrease long-term population viability (Lewontin and Cohen 1969). These site differences make it difficult to generalize patterns of survival for the species, especially in the absence of data on potential drivers of survival. For $P$. scariosus var. albifluvis, survival differences among sites were not notable. Yet the demographic analyses showed that the Watson population had a higher population growth rate and much lower probability of extinction than the White River population. This discrepancy may have to do with the fact that Watson had fewer years of monitoring data, and the data gap occurred during years with the lowest survival rates for White River. Therefore, the survival rates for Watson are higher on average (and fewer in number) than those from White River. It is possible that with future monitoring at these 2 sites, differences in growth rate and viability predictions will diminish. Understanding both site and species variability is critical to understanding vulnerability of the 2 species across their complete ranges. We currently monitor 3 additional demographic plots (2 for P. grahamii and one for P. scariosus var. albifluvis) that were established in 2010 , and we continue to monitor the 4 long-term sites. The addition of new sites to future analyses will allow us to gain a broader understanding of population dynamics across the species' ranges.

The stable adult age class and longevity of these 2 species makes it hard to detect declines in the species. Because adult plants appeared to have high and consistent survival, populations may persist in the absence of significant recruitment for quite some time without showing any significant declines. This is problematic, because if a deterministic or stochastic event eliminated a significant proportion of the adult population and if recruitment continued to be low and infrequent, the population may not have the ability to recover. Therefore, while counts of adult plants can be a useful gauge of population growth and viability, documenting the frequency and magnitude of recruitment events will continue to be important to understanding long-term dynamics. However, longer-lived plant species such as these may be less vulnerable to the effects of future changes in climate variability (Morris et al. 2008, Dalgleish et al. 2010), because survival in adults is high and stable compared to survival in shorter-lived species.

\section{Relationship to Environmental Variables}

Discerning what environmental drivers may be affecting population dynamics of a given population or species is a notoriously difficult question in population ecology (Knape and de Valpine 2011) and generally requires consistent, long-term data with strong patterns. It was expected on the basis of anecdotal observations that reproduction variables would have a relationship with seasonal or annual precipitation. However, this relationship was not seen for either species. This outcome could have occurred for a number or reasons. First, we may not have measured the right relationship. Although we examined several different permutations of annual and seasonal precipitation measurements, it is possible that some other weather variable or precipitation measure drove recruitment on given years. Second, regional weather stations may not be capturing important site-level environmental drivers. Local topography, weather patterns, and other variables may be more important to population dynamics in these 2 
species than regionally captured precipitation patterns. Finally, precipitation patterns may have a relationship with population vital rates or abundances that is masked by the effects of another variable, such as herbivory or erosion at the sites. Further studies would be necessary to determine if multiple environmental or deterministic drivers of population dynamics are operating in simultaneous, and possibly contradictory, ways in these populations.

\section{Conclusions}

Penstemon grahamii and P. scariosus var. albifluvis are 2 rare species of beardtongue with narrow distributions and small population sizes. While plant abundances appeared to be largely stable over this monitoring period, recruitment has been low and sporadic, and several of the population growth rate estimates indicate that populations may be in slow decline. When population growth rates are close to one, any number of stressors could cause these apparently stable populations to decline. Additionally, increases or changes in stressors could exacerbate declines in populations already exhibiting stochastic dynamics. Habitat destruction due to energy development, increased aridity, stock grazing, and native small mammal and insect herbivory have all been hypothesized to have a negative effect on the dynamics of these populations. Targeted studies at these focal sites could help determine the importance of these and other potential stressors on population dynamics into the future.

Further demographic monitoring at these sites will be useful for determining potential drivers of vital rate and population growth rate variation in the 2 species, and can help place broader surveys of the 2 species in context. We are continuing to monitor these sites, as well as other sites, and are undertaking more detailed studies of recruitment processes in order to increase the robustness of our analyses and to better understand population dynamics across the species' ranges. In the future, it would also be useful to understand how the demography and population dynamics of these rare species compare to more common nearby penstemon species such as Penstemon fremontii. This type of work could help place our results into a broader context and increase understanding of beardtongue ecology across the region.
Energy development in the western United States will continue into the foreseeable future, and will have a diversity of consequences for native plant and animal species, from wide-ranging mammal and bird species to rare and narrowly distributed plant species. This study provides a critical demographic analysis of rare beardtongue populations that are likely to be impacted by future energy exploration and development. Our methods and approaches could be useful for studying other rare endemic plant species that are likely to be impacted by ongoing energy development, and our results may be relevant to other species with similar life histories. Small population sizes and limited recruitment are cause for caution and concern when determining whether these species can withstand the disturbance associated with energy development in the region.

\section{ACKNOWLEDGMENTS}

We thank J. Lewinsohn, V. Tepedino, and S. Torti for establishing the project, R. Bolander for project support, and the many field assistants and volunteers of the Red Butte Garden and Arboretum who collected data throughout the study period. Thanks to M. Ellis and 2 anonymous reviewers for comments on previous versions of this manuscript. Funding for this project was provided by the U.S. Bureau of Land Management Utah State office, the U.S. Fish and Wildlife Service, and the University of Utah. Any use of trade, firm, or product names is for descriptive purposes only and does not imply endorsement by the U.S. government.

\section{Literature Cited}

Adams, V.M., D.M. Marsh, and J.S. Knox. 2005. Importance of the seed bank for population viability and population monitoring in a threatened wetland herb. Biological Conservation 124:425-436.

Bergquist, E., P. Evangelista, T.J. Stohlgren, and N. AlLEY. 2007. Invasive species and coal bed methane development in the Powder River Basin, Wyoming. Environmental Monitoring and Assessment 128: 381-394.

Boutin, S., M.S. Boyce, M. Hebblewhite, D. Hervieux, K.H. KNOPFF, M.C. Latham, D.M. LaThaM, J. NaGY, D. Seip, and R. Serrouya. 2012. Why are caribou declining in the oil sands? Frontiers in Ecology and Environment 10:65-67.

Burnham, K.P., And D.R. Anderson. 2002. Model selection and inference: a practical information-theoretic approach. Springer, New York, NY. 
Caswell, H. 2001. Matrix population models: construction, analysis, and interpretation. 2nd edition. Sinauer Associates, Sunderland.

Chow, J., R.J. Kopp, and P.R. Pontney. 2003. Energy resources and global development. Science 302: $1528-1531$.

Copeland, H.E., K.E. Doherty, D.E. Naugle, A. Pocewicz, and J.M. Kiesecker. 2009. Mapping oil and gas development potential in the US Intermountain West and estimating impacts to species. PLOS ONE 4:1-7.

Crone, E.E., E.S. Menges, M.M. Ellis, T. Bell, P. Bierzychudek, J. Ehrlen, T.N. Kaye, T.M. Knight, P. Lesica, W.F. Morris, ET AL. 2011. How do plant ecologists use matrix population models? Ecology Letters 14:1-8.

Dalgleish, H.J., D.N. Koons, AND P.B. Adler. 2010. Can life-history traits predict the response of forb populations to changes in climate variability? Journal of Ecology 98:209-217.

Dodge, R., AND W. YaTES. 2009. 2009 status report demographic monitoring and pollination biology for Penstemon scariosus var. albifluvis and Penstemon grahamii in Uintah County, Utah. Bureau of Land Management, Utah State Office. 27 pp.

Doherty, K.E., D.E. Naugle, B.L. Walker, and J.M. Graнam. 2008. Greater Sage-Grouse winter habitat selection and energy development. Journal of Wildlife Management 72:187-195.

Ellis, M.M., J.L. Williams, P. Lesica, T.J. Bell, P. Bierzychudek, M. Bowles, E.E. Crone, D.F. Doak, J. Ehrln, A. Ellis-Adam, ET AL. 2012. Matrix population models from 20 studies of perennial plant populations: Ecological Archives E093-083. Ecology 93:951.

Hervieux, D., M. Hebblewhite, N.J. DeCesare, S. Boutin, M. Russell, and S. Robertson. 2013. Widespread and drastic declines in woodland caribou (Rangifer tarandus cairbou) continue unabated in Alberta. Canadian Journal of Zoology 91:872-882.

Higgins, S.I., S.T.A. Pickett, and W.J. Bond. 2000. Predicting extinction risks for plants: environmental stochasticity can save declining populations. Trends in Ecology and Evolution 15:516-520.

Humbert, J.-Y., L.S. Mills, J.S. Horne, and B. Dennis. 2009. A better way to estimate population trends. Oikos 118:1940-1946.

Humphrey, L.D., AND E.W. Schupp. 1999. Temporal patterns of seedling emergence and early survival of Great Basin perennial plant species. Great Basin Naturalist 59:35-49.

Kaye, T.N., AND D.A. PyKe. 2003. The effect of stochastic technique on estimates of population viability from transition matrix models. Ecology 84:1464-1476.

Kery, M., K.B. Gregg, and M. Schaub. 2005. Demographic estimation methods for plants with unobservable life-states. Oikos 108:307-320.

KNAPE, J., AND P. DE VALPINE. 2011. Effects of weather and climate on the dynamics of animal population time series. Proceedings of the Royal Society B-Biological Sciences 278:985-992.

Lauenroth, W.K., And P.B. Adler. 2008. Demography of perennial grassland plants: survival, life expectancy, and life span. Journal of Ecology 96:1023-1032.

Lebreton, J.D., K.P. Burnham, J. Clobert, and D.R. ANDERSON. 1992. Modeling survival and testing biological hypotheses using marked animals: a unified approach with case studies. Ecological Monographs 62:67-118.

LesicA, P. 1995. Demography of Astragalus scaphoides and effects of herbivory on population growth. Great Basin Naturalist 55:142-150.

Lesica, P., and E.E. Crone. 2007. Causes and consequences of prolonged dormancy for an iteroparous geophyte, Silene spaldingii. Journal of Ecology 95:1360-1369.

Lewinsohn, J.S., and V.J. Tepedino. 2007. Breeding biology and flower visitors of the rare white river penstemon, Penstemon scariosus var. albifluvis (Scrophulariaceae). Western North American Naturalist 67:232-237.

Lewontin, R.C., and D. Cohen. 1969. On population growth in a randomly varying environment. Proceedings of the National Academy of Sciences 62: 1056-1060.

Mabry, C. 2011. Survival, reproductive output, and transplant potential of Penstemon tubiflorus (tube penstemon). Western North American Naturalist $71: 17-24$.

Mace, G.M., and M. Kershaw. 1997. Extinction risk and rarity on an ecological timescale. Pages 130-149 in W.E. Kunin and K.J. Gaston, editors, The biology of rarity. Chapman and Hall, London.

Menges, E.S. 2000. Population viability analyses in plants: challenges and opportunities. Trends in Ecology and Evolution 15:51-56.

Morris, W.F., AND D.F. DOAK. 2002. Quantitative conservation biology. Sinauer Associates, Inc., Sunderland.

Morris, W.F., C.A. Pfister, S. Tuljapurkar, C.V. Haridas, C.L. Boggs, M.S. Boyce, E. Bruna, D.R. Church, T. Coulson, D.F. Doak, et al. 2008. Longevity can buffer plant and animal populations against changing climate variability. Ecology 89:19-25.

Naugle, D., K. Doherty, B. Walker, M. Holloran, and H. Copeland. 2011. Greater Sage-Grouse and energy development in western North America. Pages 489-503 in S.T. Knick and J.W. Connelly, editors, Greater Sage-Grouse: ecology and conservation of a landscape species and its habitats. Studies in Avian Biology 38, University of California Press, Berkeley, CA.

Purvis, A., J.L. Gittleman, G. Cowlishaw, and G.M. MACE. 2000. Predicting extinction risk in declining species. Proceedings of the Royal Society of London Series B 267:1699-1704.

R Core Development Team. 2004. R: a language and environment for statistical computing. R Foundation for Statistical Computing, Vienna, Austria.

Shefferson, R.P., B.K. Sandercock, J. Proper, and S.R. BEISSINGER. 2001. Estimating dormancy and survival of a rare herbaceous perennial using markrecapture models. Ecology 82:145-156.

Tepedino, V.J., T.R. Toler, B.A. BRadley, J.L. Hawk, AND T.L. GRISWOLD. 2007. Pollination biology of a disjunct population of the endangered sandhills endemic Penstemon haydenii S. Wats. (Scrophulariaceae) in Wyoming, USA. Plant Ecology 193:59-69.

Thomson, D.M. 2005. Matrix models as a tool for understanding invasive plant and native plant interactions. Conservation Biology 19:917-928.

[USFWS] U.S. Fish and Wildlife Service. 2012. Species Status Assessment, Penstemon Expert's Meeting 2012. Salt Lake City, UT. 6 pp. 
2013. Endangered and threatened wildlife and plants; threatened species status for Graham's beardtongue (Penstemon grahamii) and White River beardtongue (Penstemon scariosus var. albifluvis). Federal Register 78:47590-47611.

Walker, B.L., D.E. Naugle, K.E. Doherty, and T.E Cornish. 2007. West Nile virus and Greater SageGrouse: estimating infection rate in a wild bird population. Avian Diseases 51:691-696.

Walston, L.J., B.L. Cantwell, and J.R. Krummel. 2009. Quantifying spatiotemporal changes in a sagebrush ecosystem in relation to energy development. Ecography 32:943-952.

White, G.C., AND K.P. Burnham. 1999. Program MARK: survival estimation from populations of marked animals. Bird Study 46 (Supplement):120-138.
White, G.C., B.E. Kendall, and R.J. Barker. 2006. Multistate survival models and their extensions in Program MARK. Journal of Wildlife Management 70:1521-1529.

Wilson, R.R., J.R. Liebezeit, and W.L. Loya. 2013. Accounting for uncertainty in oil and gas development impacts to wildlife in Alaska. Conservation Letters 6:350-358.

Received 1 July 2013 Accepted 23 June 2014 